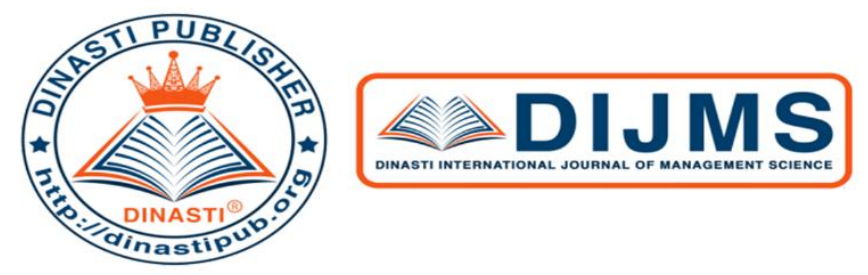

+6281387654578

+6281387654578 (Q)

https://dinastipub.org/DIJMS (4)

dinasti-info@gmail.com (๑)

\title{
IMPLEMENTATION OF GOOD CORPORATE GOVERNANCE PRINCIPLES IN PT. X AS A TRANSPORT SERVICE COMPANY JAKARTA - KALIMANTAN
}

\section{Silvia Ersa Rahmadania}

Universitas Mercu Buana, Jakarta - Indonesia

\begin{tabular}{|c|c|}
\hline $\begin{array}{c}\text { ARTICLE INFORMATION } \\
\text { Received: } 17^{\text {th }} \text { May } 2020 \\
\text { Revised: } 19^{\text {th }} \text { June } 2020 \\
\text { Issued: } 19^{\text {th }} \text { July } 2020 \\
\text { Corresponding author: first author } \\
\text { E-mail: } \\
\text { silviaersa.ser@gmail.com }\end{array}$ & $\begin{array}{l}\text { Abstract: With so many companies that have emerged } \\
\text { and can evolve over time, now the family company has } \\
\text { experienced rapid progress. This article was created } \\
\text { with the aim of being able to discuss the application of } \\
\text { the principles of Good Corporate Governance in family } \\
\text { businesses. PT. X which is engaged in heavy } \\
\text { equipment transportation services and has two offices } \\
\text { in different regions. By using descriptive qualitative } \\
\text { analysis methods in order to provide good information } \\
\text { and understand the principles of Good Corporate } \\
\text { Governance. Based on the results of the study it can be } \\
\text { concluded that PT. X must face problems in the } \\
\text { application of the principle of corporate accountability } \\
\text { is still not able to apply the job desk properly so that in } \\
\text { the implementation of the job desk that is implemented } \\
\text { still does not meet the principle of independence. So } \\
\text { the company is expected to be able to better organize } \\
\text { the organizational structure and by using the Family } \\
\text { Owned Enterprise (FOE) family company so that the } \\
\text { principles of Good Corporate Governance can be better } \\
\text { applied to the company. }\end{array}$ \\
\hline
\end{tabular}

\section{INTRODUCTION}

Nowadays many businesses created by new companies that appear to be able to compete and try to develop like other companies that have been established for a long time. Various types of businesses owned by many companies starting from family companies and non-family companies. A business that is said to be a family company is that if the business is the majority of its shareholders and or is owned by the founder is also controlled and managed by people who are related by family or brotherhood. 
In general, there are indeed many who consider that this family company is a small company whose management is minimal with knowledge when compared to non-family companies. But the reality cannot be underestimated just like that, because in this day and age there are many family companies that have imported and exported with currency and quantity that are not small. This can happen of course because many family companies now use workers who have expertise in their fields and work professionally so that it can have a positive impact on the family company.

This research was conducted at PT. X, which operates as a heavy equipment transport company operating in the Kalimantan region and has an office as a supervisory management that manages or controls all transactions starting from buying or selling in the West Jakarta area. This company has been established since 2000, which can be said as a family company because the majority of founders and shareholders in this company have a bond or a kinship. PT. X operates to run transportation services and has vehicles in the form of the tronton car and excavators in the Kalimantan area, and has an office in the Jakarta area which is intended as a management that manages, controls, controls, and also makes all reports received at the Kalimantan office.

The purpose of this transport service company is of course wanting to get as much profit as the company that engages in the transportation of heavy equipment rental services such as transporting lumber the tronton car or excavator and with the above objectives, the company must be able to get customer loyalty by creating customer satisfaction by maintaining good relationship. Companies are required to be able to work effectively and efficiently. Effective in completing work in accordance with what is desired by the customer as well as efficient, namely working by using appropriate resources and energy without waste.

In obtaining success for the realization of a company's goals in gaining customer loyalty, the company must have competent human resources in accordance with their respective functions. Thus the company must certainly be able to have competent quality human resources to be able to complete the work as fully as possible.

But the phenomenon that occurred at PT. X as one of the companies included in this family company has not been able to apply the principles of Good Corporate Governance in managing the company because the company still does not have an organizational structure and the impact on the job desk is still unclear. With this phenomenon, the researchers try to be able to know and understand the application of PT. X as a family company that is engaged in heavy equipment transportation services regarding the principles of Good Corporate Governance.

The purpose of this study is to be able to apply the principles of Good Corporate Governance in family companies especially PT. X. A good corporate governance system is based on the establishment and implementation of the principles of corporate governance (GCG) in the company's managerial process. By recognizing these universally applicable principles, it is hoped that a company can live sustainably and provide benefits to its stakeholders.

\section{LITERATURE REVIEW \\ Definition Good Governance Corporate}

Separation of ownership or shareholders with business control and or also called managers regarding the certainty of funds invested smoothly and well is not being taken over can lead to the occurrence of corporate governance, which is carried out to create a structured series of processes and is used to manage as well as direct or lead business with the aim of 
being able to create added value for all interested parties. Corporate governance is a series of processes, habits, policies, rules, and institutions that affect the direction, management, and control of a company or corporation (Ali, 2016).

According to Sutedi (2011) Corporate governance is a series of processes or structures used by interested parties to improve business success while realizing shareholder value in the long term while taking into account the interests of other stakeholders based on the constitution and business ethics. Good Corporate Governance is also a principle that directs and controls the company in order to achieve a balance between the strength and authority of the company in providing accountability to shareholders in particular and stakeholders in general (Komite Cadburry in Nugroho \& Arijanto, 2015).

Based on the statements above, it can be concluded that Good Corporate Governance is a system, structure, sequence and process that can be used as a direction in managing, controlling, checking or considering the company's authority with the aim of being able to increase the value of shareholders (stakeholder value) by allocating various parties an interest in the company that can limit the emergence of opportunities for mismanagement and misuse of assets.

\section{Purpose Good Corporate Governance}

Good corporate governance is needed to encourage the creation of markets that are efficient, transparent and consistent with laws and regulations. The purpose of Good Corporate Governance is in addition to providing fair protection and protection to shareholders or owners and other interested parties based on increasing shareholder value. There are five main types of objectives of good corporate governance, namely:

1) Protect the rights, obligations and interests of shareholders.

2) Protect the rights, obligations and interests of other stakeholders.

3) Increase the value of the company and its shareholders

4) Increase the effectiveness and efficiency of the work of company management.

5) Improve the quality of senior management and senior management relations with the company.

\section{Benefit Corporate Governance}

By implementing or implementing corporate governance, there are several benefits that can be obtained based on the Forum for Coporate Governance in Indonesia (Ali, 2016), including:

1) Improve company performance through the creation of a better decision making process, improve company operational efficiency and further improve services to stakeholders.

2) Make it easier to obtain funding that is cheaper and not rigid (due to trust factors) which will ultimately increase corporate value.

3) Restoring investor confidence to invest in Indonesia.

4) Shareholders will feel satisfied with the company's performance because it will simultaneously increase shareholder's value and dividends.

\section{Principle Good Corporate Governance}

The principles of good corporate governance and have been prepared and harmonized with the legal system, rules and values that apply in their respective countries, among others:

1. Accountability, contains the authority that must be possessed by the top brass and their obligations to shareholders and other stakeholders. 
2. Responsibility, requires leaders and managers of the company to be responsible in carrying out its activities.

3. Transparancy, disclosing information accurately and timely in accordance with company circumstances.

4. Fairness, all stakeholders must have the opportunity to get fair treatment from the company.

5. Independency, requires managers to be able to act independently according to their roles and functions without pressure from any party that is not in accordance with the prevailing operating system of the company.

\section{Application Factor Good Corporate Governance}

1) External factors, several factors originating from outside the company that greatly affect the successful implementation of Good Corporate Governance, including:

a) The existence of a good legal system so as to guarantee the implementation of consistent and effective rule of law.

b) Support the implementation of GCG from the public sector or government institutions which are expected to also be able to implement Good Governance and Clean Government towards actual Good Governance.

c) As an example of the implementation of good corporate governance that is best (best practices) that can become an effective and professional GCG implementation standard

2) Internal factors, driving the success of the implementation of Good Corporate Governance practices that originate from within the company. Some factors include:

a) There is a corporate culture that supports the implementation of GCG in the mechanism and work management system in the company.

b) Various regulations and policies issued by the company refer to the application of GCG values.

c) Management of control over company risk can also be based on GCG standard rules.

d) The existence of an effective audit system (inspection) in the company to avoid any irregularities that might occur.

e) The existence of information disclosure for the public to be able to understand every move and step of management in the company so that the public can understand and follow every step of the company's development and dynamics from time to time

\section{Conflict in Family Companies}

Family business is an organization founded by the co-founder or a family member. Founded with the same goal and managed by one of his siblings or blood relatives. Thus, all decisions in the company or organization must go through collective bargaining until the right decision is found and the organization is established with joint responsibility. According to Andypratama \& Mustamu (2013) this family company has 2 types, namely:

1) Family Owned Enterprise (FOE), a company owned by family members or siblings but the company is managed by professional executives from outside the family environment.

2) Family Business Enterprise (FBE), a company owned and also managed by a family or siblings who are also the founders.

Most family companies in the State of Indonesia are family businesses with FBE type, with this type of conflict often occurring in the management of family companies that have been established between families because each founder or owner has a trusted person or 
controller for his own interests. Besides family businesses are more likely to have a culture or habits that are based on relationships rather than based on rules, it is more likely to be a conflict between family members in the company so that it can have a negative impact on long-term internal and external factors.

\section{RESEARCH METHODS}

This research article uses a descriptive method of writing that presents, analyzes and interprets data based on the implementation of corporate governance principles at PT. X as a transportation services company. Descriptive analysis is used to describe and describe the variables used in this study (Ghozali, 2015). Descriptive analysis is a statistic that is used to analyze data by describing or describing the data that has been collected as it is without intending to make conclusions that apply to the general public or generation (Sugiyono, 2017).

The research data used are qualitative, in qualitative research it must emphasize the importance of closeness with people as well as the research situation so that a clear understanding of the real conditions and adjusting reality can be obtained. This data collection method is mostly obtained directly based on secondary data and various references such as journals, articles and books that have links to Good Corporate Governance.

\section{FINDINGS AND DISCUSSION \\ Company Profile \\ Vision and Mission PT. $X$ \\ Vision}

Being a company that can act and provide policy values consistent with the company's business ethics with professionalism in mastering the work undertaken, also guarantees safety by minimizing the risk of accidents in order to protect the company's assets from possible losses.

\section{Mission}

1) Providing transportation services that are prominent and well-known, are excellent services and provide services according to quality standards according to expectations or even exceeding expectations.

2) Providing leading company solutions, is a business in providing total services so that it always becomes a customer solution and can increase work productivity.

3) Making services that can be enjoyed and met by customers in the Indonesian region so that the company can further expand its business network.

4) Marketing quality service coverage according to standards for customers in various regions by developing business networks using regional expansion.

5) Maintaining and improving the services provided to customers by controlling the cost of service

\section{Principle Good Corporate Governance PT. X}

\section{Accountability}

In the company PT. $X$ in corporate accountability must have a vision and mission that is well implemented. The vision adopted by PT. X as a family company in the field of heavy equipment transportation services that must be a company that has policies that are consistent with the values of professional business ethics also ensure safety in order to safeguard company assets. The organizational structure owned by PT. X must use the 
decisions, agreements and negotiations of family members who have an interest in the company made through negotiations and by providing input to improve the performance and objectives of the company. Ownership of PT. X is given to Mr. F and founded the company through investment with friends and relatives namely Mr. Q. Because these two leaders do have the same goal to establish and grow a company even as a family company. The company itself is managed or run by Mr. M (the youngest child of Mr. T) who holds and manages company cash, especially the company's office located in Jakarta.

PT. X has a standard of work in the office must use clothes that are polite and neat but does not require to use shoes or shirts, have employees who are polite and orderly, the most important work that is given can be carried out in a timely manner and well done. Viewed based on the operational system, PT. X has a subscription and searches for content based on the subscription he has.

If the cargo has been obtained, the subscription will make a BA (minutes) to determine the price and the amount of tonnage and the period to be transported or carried out, after agreed by both parties (PT. X and customers) the goods will be transported to the tronton or exca according to the time a specified period after arriving at the specified destination will be unloaded. Based on the operational system owned by PT. X can be seen that the performance structure owned by PT. X already has the right order or work rules and is well lived in order to get customer loyalty.

The division of tasks and work responsibilities that exist in the work rules of the company has been handed over to employees in their respective fields and managed by one of the family members Mr. T who leads or controls the office in the Kalimantan area is $\mathrm{Mr}$. H. In conclusion, the majority of corporate responsibility is managed by family members of shareholders, with responsibilities that are managed jointly and decisions taken by deliberation will affect good performance in the company. Control of company assets, then PT. X routinely checks and services every unit of car, truck, and exca to keep it fit for use. The performance evaluation system is done by asking the mechanics as well as drivers who have sent the cargo and have finished unloading.

\section{Responsibility}

This responsibility includes discussions on labor rights, consumers, how to compete with companies, CSR implemented by companies, as well as the welfare of PT. X. The company has provided salary in Central Kalimantan UMP of 2.9 million rupiahs as well as health insurance costs directly funded by the office. Consumer protection implemented by the company is by sending the cargo within the agreed period of time for both parties. Before traveling, the company always carries out routine checks so as to minimize all obstacles that could interfere with the trip and maintain the security of the customer's cargo. So far the company has been competing in a healthy manner with the existing business ethics values, namely by maintaining good relations with other transportation services business relationships and giving the same business partner with an excessive load with the calculations that have been adjusted by both parties.

PT. X has obedience to the tax constitution by always paying income tax on time and has a permit to operate, every delivery of goods made is always subject to VAT to comply with government policies. Whereas on employee welfare, the company has provided salaries in accordance with DKI Jakarta's UMR nominal for offices in Jakarta and UMP Kalimantan for offices in Kalimantan. The company also provides employees convenience in terms of transportation such as lending vehicles, covering the costs of 
parking, gasoline and other official travel, provides holiday allowances (THR), does not provide regulations that make it difficult for employees and also operates a daily food allowance system that is given weekly. The company also values and protects employees by providing health insurance and if there are personal problems employees are allowed to leave the office if it is urgent.

\section{Transparancy}

Discussed for stakeholders such as customers, business relations, shareholders, the government and the surrounding community. The company is always open in all respects to members of the organization concerned and gives obligations to employees to provide work and financial reports every month. Likewise with the laws and regulations governed by the government, the company already has a permit to operate so that in carrying out the load will be able to minimize unwanted constraints or hinder work, pay and also report taxes on time and charge VAT on each trip or cargo that is delivered to the destination. Thus the company will easily know the increase and decrease, and can find the right solution together. The company also always prioritizes customer satisfaction in order to create customer loyalty. In addition, the company also provides regular contributions to the surrounding environment, such as donating holidays, contributing large events commemorated by the environment, and so on. This is certainly done so that the journey carried out in delivering the cargo to the destination according to consumer demand will be able to run safely and smoothly without any obstacles.

\section{Fairness}

PT. X always prioritizes the rights and obligations of the customer so that it also invites customers to provide criticism and suggestions if they do have complaints about the services provided by the company. Do not forget to invite the environment or the outside community who feel uncomfortable and want to give criticism to the company. But so far the company still looks fine in carrying out performance standards so there is no criticism from outside or customers. In recruiting company employees, accepting employees with a minimum of graduation is a junior high school, which usually can be employed as a mechanic or driver, has prior work experience, has no physical or health disabilities, is polite, has the expertise required in the field.

The company also highly appreciates the persistence of employees at work, will provide a bonus if the work produced exceeds the performance standards required by the company. Vice versa, employees will get verbal reprimands (mild) if they make mistakes in work also provide harsh sanctions if not honest in work. Employees who have long worked will get facilities such as laptops, motorcycles and others.

\section{Independency}

Decision making determined by the company is an authority made based on joint decisions with family members who are members of interested organizations in the company. Because family members are very important in managing the company's performance PT. X. Controlling is always done at least once a month by bringing these senior members of the brothers to the office to see the extent to which employees comply with the employee's work rules and reports that have been completed by the employee. Especially tax payment documents that have been reported online. For the Kalimantan office, Mr. $\mathrm{H}$ by bringing the reports needed for inspection at the Jakarta office. 
GCG principles that are applied to transportation service companies, especially as a family company in Indonesia, namely PT. This X can be pretty good. It's just that it has to be more focused and rethought about the job desk owned in the organizational structure that is still controlled by the family so that the decision making so far has only been made based on the results of negotiations with family members who are interested in the company, but behind the decision making process respectively - each of the interested family members has different controls so that the results can have an impact on the slow pace of company improvement.

In addition, the company is also seen still using double job desks to several employees who have expertise, skills, workmanlike and quick in catching new things. The double job desk occurs because the owner or shareholder has a calculation regarding the debts of the company so that it can be resolved quickly so as to minimize the cost of adding employees and using employees who have been owned by providing jobs outside the job desk from their fields and giving bonuses if they can complete the work the side requested by the shareholders. When compared to providing salary or compensation to several new employees, the costs incurred would be more efficient if using a double job desk system. However, this creates inconvenience to the employees, which creates stress or workload on the employees.

\section{CONCLUSION AND SUGESTION CONCLUSION}

From the results of research conducted and obtained based on the principles of good corporate governance, the following conclusions can be drawn:

1) Principle of Accountability

At PT. X namely by having a vision and mission that is directed and clear, the formation of an organizational structure that runs as it should, the company's work standards such as the rules of courtesy and completing work on time, as well as operational systems that have been running smoothly according to predetermined company performance standards.

2) Liability Principle

Which is implemented by PT. X, that is by complying with labor laws by providing salaries in accordance with UMR standards and the UMP office in Kalimantan and Jakarta also provides holiday allowances for those who celebrate them. Maintain customer legislation by guaranteeing the security and safety of the cargo delivered, creating and maintaining good relations between business relationships, paying and reporting taxes and VAT on every cargo carried out and in a timely manner, having a license to operate according to government regulations, not forgetting to give a message to the surrounding community in order to maintain travel security and not hamper work, provide employee welfare by providing facilities as needed and needs.

3) Openness Principle

Which is applied by PT. X aims to provide and convey good and correct information to shareholders in the company who are also family members or relatives of the manager or founder of the company and other company members such as business relations, employees, customers, the surrounding community, and also the government.

4) Fairness Principle

The company always gives the rights and obligations of consumers to provide criticism as well as suggestions so that it can be used as a performance evaluation material for 
the company. Also gives the right of the surrounding community to be able to provide criticism, conduct a recruitment system with the standards set by the company, treat employees fairly, and provide bonuses for the achievement of work performance given to the company.

5) Independence Principle

The PT. X by involving family members who have an interest in the company to manage it also establishes the company in controlling the company, by directly involving the company's performance and complying with government regulations.

\section{SUGESTION}

Based on the conclusions of the research results obtained as for the advice to be given by the author, with the hope that it can be taken into consideration for the management of the company and the development of family companies, especially PT. X which is engaged in heavy equipment transportation services:

1) Organizational structure that is owned can be seen not going well if it still associates with the family element that is used as an authority in deciding agreements and agreed together. By using FOE (Family Owned Enterprise) family companies, it is expected that the organizational structure will be even better so that the performance produced by the company can run effectively and regularly.

2) Companies will further implement openness by using websites, social media, etc. for advertising so that the company is better known and able to expand its business reach. This will certainly improve the resulting performance.

3) The company will pay more attention to the work comfort of employees regarding the job desk owned and improve the existing organizational structure. To produce effective and efficient performance. 


\section{REFERENCES}

Agoes, S., \& Ardana, I. (2009). Etika Bisnis dan Profesi "Tantangan Membangun Manusia Seutuhnya. Jakarta: Salemba Empat.

Ali, H. (2020). Modul Business Ethics \& GG Ethics of Consumer Protection. Jakarta: Universitas Mercubuana.

Andypratama, L. W., \& Mustamu, R. H. (2013). Penerapan Prinsip-Prinsip Good Corporate CGovernance Pada Perusahaan Keluarga: Studi Deskriptif Distributor Makanan. Jurnal EMBA, 1., (1)., 1-11.

Arief, H. M. (2019). Business Ethic and Good Governance (BE \& GG) Etika Bisnis Pada PT. Sucaco Tbk. Jurnal Ilmu Manajemen Terapan (JIMT'), 1., (2)., 153-161.

Arijanto, A. (2014). Etika Bisnis bagi Pelaku Bisnis (Cara cerdas dalam memahami konsep dan faktor-faktor etika bisnis dengan beberapa contoh praktis) Edisi Ketiga. Jakarta: Raja Grafindo Persada.

Ghozali , I. (2015). Aplikasi Analisis Multivariate dengan Program IBM SPSS.23. Semarang: Universitas Diponegoro.

Ghozali, I. (2013). Aplikasi Analisis Multivariate dengan Program IBM SPSS.21. Semarang: Universitas Diponegoro.

Kusmiarti, P. (2020). Implementasi Etika Bisnis Dan Good Corporate Governance pada Perkebunan Kelapa Sawit PT. Bumitama Gunajaya Agro. Jurnal Ilmu Manajemen Terapan, 1., (3)., 196-210.

Pratiwi, D., Mulyawan, S., \& Lino, Z. E. (2020). The Role Of Corporate On Governance On Financial Statement Quality And Investor Reaction. Dinasti International Journal of Economics Finance \& Accounting, 1., (1)., 31-39.

Sugiyono . (2017). Metode Penelitian Pendidikan Pendekatan Kuantitatif, Kualitatif dan $R \& D$. Bandung: Alfabeta.

Sutedi, A. (2011). Good Corporate Governance. Jakarta: Sinar Grafika.

Wulandari, D. R., \& Ali, H. (2018, October Senin). Business Ethics \& Good Governance Penerapan Etika Bisnis Pada Perusahaan The Body Shop. Diambil kembali dari Slideshare.net: https://www.slideshare.net/dyahruthw/7beampggdyah-ruthwulandarihapzi-alietika-amp-bisnisetika-bisnis-the-body-shop-universitas-mercubuana2018docx 